Berisha Ajvaz, Koca Afrim, Berisha Kushtrim. Application of taxonomy analysis in selection of young sportsman in karate and football. Journal of Education, Health and Sport. 2019;9(2):21-29. eISNN 2391-8306. DOI http://dx.doi.org/10.5281/zenodo.2555021

http://ojs.ukw.edu.pl/index.php/johs/article/view/6547

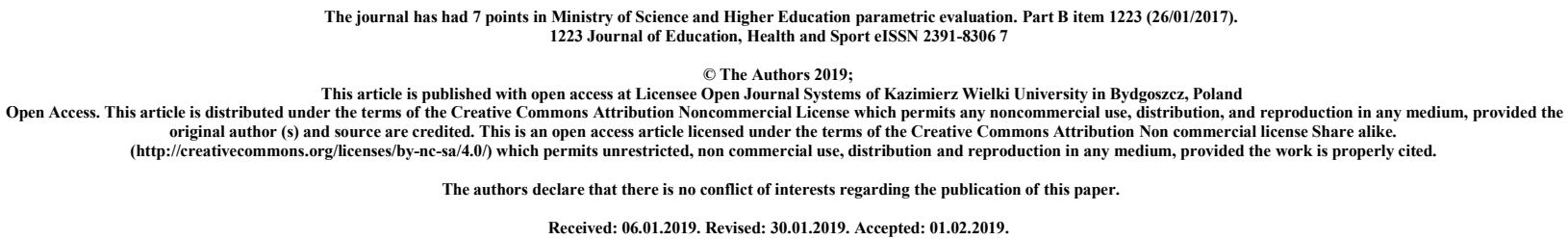

Received: 06.01.2019. Revised: 30.01.2019. Accepted: 01.02.2019.

\title{
APPLICATION OF TAXONOMY ANALYSIS IN SELECTION OF YOUNG SPORTSMAN IN KARATE AND FOOTBALL
}

\author{
Ajvaz Berisha ${ }^{1}$; Afrim Koca ${ }^{1}$; Kushtrim Berisha
}

${ }^{1}$ University Hasan Prishtina, Faculty of Physical Education and Sport, Prishtina, Kosova

\author{
*Corresponding Author: \\ Afrim Koca PhD \\ florian.miftari@uni-pr.edu
}

University Hasan Prishtina,

Faculty of Physical Education and Sport,

Prishtina, Kosova

Word count: 1580

Abstract word count: 395

Number of Tables: 2

Number of Figures: 1 


\section{ABSTRACT}

The selecting represents the optimal selection of that part of the anthropological status that is important for the success in the respective sport and that meets the specific needs of the athlete and also for the potential athlete's orientation and perfection in terms of certain sports disciplines.

Regarding the selection of the working methods in this research, there were selected those methods which are supposed to help in drawing conclusions about the nature of the problem posed. The sample was defined as students aged 12 years from the Middle School "Selami Hallaqi" Gjilan. In this study is included a total of 90 students, that is, two groups of 45 students. The first group is consisted of students who besides regular hours of physical education 2 times a week also exercised karate two more times a week by one hour per day. The second group comprised of students who besides regular hours of physical education 2 times a week, also exercised football two more times per week, by an hour a day. Measurements were made at the end of the school year. 9 motor variables were applied (Kurelić et al., 1975), running in 20 meters (MT20V), the long jump from the place (MSKDM), high jump from the place (MSKVM), hand taping (MTRUK), leg taping ( MTNOG), eight with bowing (MOSPR), running sideways (mtrs) bowing ahead in the bank (MFLPRK), legs spread apart-retaliation (MFLSP). For the processing of the results it was applied the t-test analysis for independent samples.

The basic statistical parameters of the results obtained from the students involved in the research show that the values obtained do not have an outlined asymmetry and incline to the lowest (hypo cortical). Taxonomic analysis shows that were obtained applying two groups of students divided by motor skills and gained distinction in these variables between groups is statistically significant. 
The second taxonomy of the motor skills shows that from the 90 students, young sportsmen involved in research, 56 of them can be defined as a student athlete with high motor skills to perform motor movements with explosive character which are well coordinated in time and space, with a top speed of movement segment. Motor dimensions of the explosive strength, speed segment, coordination and flexibility are important motor skills for success in a big number of sports (Findak et al., 1992; Popović, 1998).

Keywords: Students, Selections, Karate, Football, Taxonomy

\section{INTRODUCTION}

The determining of the actual situation of children is among the important motor principles in their orientation in the sport for which motor skills are responsible to achieve top results. Also, the definition of motor current situation of children is necessary to determine the current status of their early work to set the work in schools, and at the end of the school year to analyze the effect of the work (Findak et al., 1992) .

Orientation procedures and selection of athletes presents important component of the planning process in sport (Popović, 1998). Selecting the optimal selection represents that part of the anthropological status that is important for success in that specific sport and that meets the determined athlete and sportsman's orientation and perfection of potential in terms of certain sports discipline. Selection implies a dynamic and continuous process based on estimates forecast, specifically, certain indicators.

The initial selection represents the first selection, which should be given a special attention, because the very early selection enables the identification of potential, namely the identification of high motor skills of children for certain sports and their orientation to engage in the sport. Best would be to start with selection in the sensitive stage of development, or in the earliest possible stage of development, due to the demands of sports, as well as due to the action in the development of certain motor skills and certain anthropological characteristics.

The initial selection represents the first and most sensitive stage in the field of sport to the ultimate success of the athlete in the specific sport. For this purpose, in this regard there were used various methods in gathering information. One of the methods to be applied in the selection of children in the sport of karate would be the application of taxonomy analysis in motor variables. 
The purpose of this research is based on the taxonomy analysis in the motor variables determining the current motor situation of children and selection of those children with higher motor skills as selected students with great opportunities to achieve top results in the sport Karate.

\section{MATERIAL \& METHOD}

The sample of the entity consists of students of the age of 12 years old from the Elementary Middle School "Selami Hallaqi" Gjilan. In this study were included a total of 90 students. The first group comprised of students who besides the regular hours of physical education that is 2 times a week, they also exercised in the sport of karate two more times per week, one hour a day. The second group comprised of students who besides the regular hours of physical education that is 2 times a week they also exercised football two more times a week, by one hour per day. Measurements were made at the end of the school year.

For the evaluation of motor skills there were taken nine variables that cover the latent space and energetic and motor processes.

Motor variables applied:

1. Running in 20 METAR (MT20V)

2. Long jump from the place (MSKDM)

3. Long jump from the place (MSKVM)

4. Hand taping (MTRUK)

5. Walk taping (MTNOG)

6. Eights with bowing (MOSPR)

7. Running sideways (MTRS)

8. Bowing ahead in the bank (MFLPRK)

9. Legs sideways-retaliation (MFLSP).

The data collection was analyzed by mathematical statistical package; SPPS program, version 23.0 of Windows. To determine the level of motor skills and the selection of children on those motor skills were applied the taxonomy analysis. 


\section{RESULTS}

Taxonomy analysis is used for the purpose of forming a sub-sample (sub-sample) with as many similar motor skills as possible. This method is a hierarchical method based on an iterative process (iterative), as a merger of entities in groups, so in the pronounced phase are joined the subjects of previously formed groups, which means that newly formed groups only expand and added to new entities under the motor specifications, and that there is no possibility of transferring subjects from one group formed in the other groups. Motor sub-spaces are covered with two variables, except for the speed in which case the variables are represented by three variables.

Taxonomic analysis results are presented with a dendrogram of motor skills (Figure 1), and show that the structuring of these skills by similarity, based on motor areas defined, clearly show the homogeneity of the investigated sample of students.

In this graph is shown the so-called Dendrogram which shows graphically who related with whom. On the vertical axis there are the entities, and the horizontal distance. Thus, for example, the entities 63 and 65 are connected to the same cluster, and then this cluster is associated with the cluster that has formed entities 51 and 70 and so on coming to the formation of two groups or clusters of separate entities under their motor skills. Taxonomic analysis results showed that the structuring of these motor skills by similarity, based on defined motor fields, clearly show the homogeneity of the sample investigated. 
Figure 1. Dendrogram of motor skills

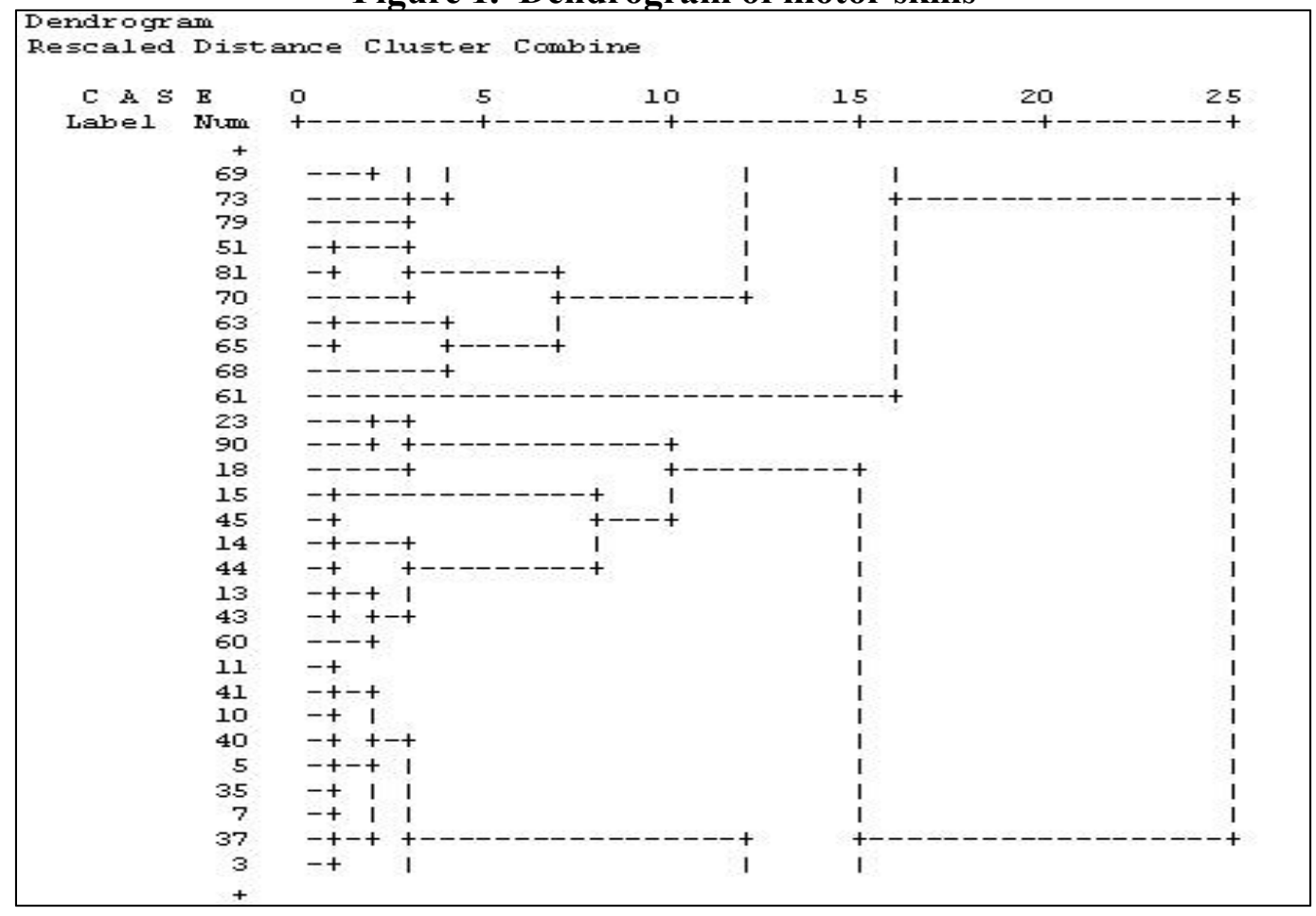

Within motor skills there are extracted two taxonomic dimensions, where based on Euclidean squared distance in the square (table 1), we see that out of 90 students in school sports sections 34 of them belong to the first taxonomic group and the second taxonomic group includes 56 student athletes. The second taxonomic dimension (Table 1) adequately defines all variables applied in this paper. The first taxonomic dimension is characterized by lower results of motor skills in all variables applied. Taxonomic analysis has divided groups of students previously involved in sports activities. (Karate and football section). 
Initial Cluster Centers

Variables

\begin{tabular}{lrrrrr}
\hline & 1 & 2 & & & \\
& $(\mathrm{~N}=34)$ & $(\mathrm{N}=56)$ & & $(\mathrm{N}=34)$ & $(\mathrm{N}=56)$ \\
MT20V & 4.46 & 3.74 & MT20V & 4.66 & 4.08 \\
MSKDM & 107.00 & 189.00 & MSKDM & 137.44 & 166.02 \\
MSKVM & 23.00 & 34.50 & MSKVM & 26.09 & 34.16 \\
MTRUK & 26.00 & 33.00 & MTRUK & 25.85 & 32.18 \\
MTNOG & 23.00 & 25.00 & MTNOG & 19.88 & 22.91 \\
MOSPR & 13.29 & 12.97 & MOSPR & 14.00 & 13.40 \\
MTRST & 10.73 & 9.40 & MTRST & 10.82 & 10.05 \\
MFLPRK & 16.00 & 33.00 & MFLPRK & 17.41 & 26.02 \\
MFLSP & 118.00 & 147.00 & MFLSP & 115.26 & 133.66 \\
& & & & \\
\hline
\end{tabular}

Final Cluster Centers

Cluster

After reviewing the size of the calculated parameters within descriptive statistics and comparison of the values between the first and second group, it is clear that students involved in sports sections belonging to the second taxonomy dominate at all determined motor skills. At the level of statistically significant variables that young athletes choose in the first taxonomy (Table 2) are motor tests that define all motor sub-areas applied in this research.

Differences obtained in the average arithmetical values between groups show that specific exercises applied during training in karate have helped to improve the execution of motor tasks in large range other than students involved in the football section. 
Table 2. Taxonomic analysis of the motor variables within and outside isolated groups

\begin{tabular}{lrrrrrr}
\hline & \multicolumn{5}{c}{ Cluster } & \multicolumn{2}{c}{ Error } & Sig. \\
Variables & Mean Square & df & Mean Square & df & \multicolumn{1}{c}{ F } & \\
\hline MT20V & 6.979 & 1 & .181 & 88 & 38.626 & .000 \\
MSKDM & 16611.157 & 1 & 120.209 & 88 & 138.186 & .000 \\
MSKVM & 1310.403 & 1 & 22.291 & 88 & 58.786 & .000 \\
MTRUK & 811.563 & 1 & 11.380 & 88 & 71.316 & .000 \\
MTNOG & 205.350 & 1 & 5.940 & 88 & 34.569 & .000 \\
MOSPR & 7.185 & 1 & .461 & 88 & 15.570 & .000 \\
MTRST & 10.587 & 1 & .446 & 88 & 23.740 & .000 \\
MFLPRK & 1681.869 & 1 & 52.366 & 88 & 32.117 & .000 \\
MFLSP & 7958.017 & 1 & 116.187 & 88 & 68.493 & .000 \\
\hline
\end{tabular}

\section{DISCUSSION}

We can conclude that the second taxonomy of motor skills shows that out of the 90 new students involved in the research, 56 of them can be defined as a student athlete with high motor skills to perform motor movements of explosive character which are well coordinated in time and space, with a top speed of movement segment. Motor dimensions of the explosive strength, speed segment, coordination and flexibility are important motor skills for success in numerous sporting disciplines, especially in the sport of karate. The results obtained show the importance that taxonomy analysis in the selection of young athletes in sports for which they have presuppositions.

Taxonomic analysis in the selection of young athletes was helped by preliminary selections of students in the sport of karate. However, out of the 45 students athletes of karate and 45 students footballers, with the application of taxonomy analysis, out of 45 footballers 11 of them may belong to or be involved in the sport of karate. We can say that the kinesiology operators well selected, adapted appropriately to the age of athletes, well applied and with a good dosage have a significant transformational impact in the selected motor skills which is proved in this research. 


\section{REFERENCES}

Arunovič, D. (1978). Uticaj posebnog programa nastave fizičog vaspitanja (sa akcentom na košarku) na neke motoričke sposobnosti učenika uzrasta 15-15 godina. Magistarska teza, Fakultet za fizičku kulturu, Beograd.

Findak,V., Metikoš,D., \& Mraković. M. (1992). Kineziološki priručnik za učitelje. Zagreb: hrvatsko pedagoško - književni zbor.

Findak, V. (1992). Metodički organizacijski oblici rada u edukaciji, športu i športskojrekreaciji. [Methodological organisational work forms in education, sport and sportrecreation.] Zagreb: Hrvatski savez za športsku rekreaciju, MENTOREX.

Ismail, A.H. (1976) Djelovanje dobro organiziranog programa fizičkog odgoja na intelektualni status. Kineziologija, Zagreb, vol. 6, br. 1-2, str. 29-37.

Kurelić, N., Momirović, K., Stojanović, M., Šturm, J., Radojević, Đ., \& Viskić-Štalec, N. (1975). Struktura i razvoj morfoloških i motoričkih dimenzija omladine. Beograd: Institut za naučna istraživanja Fakulteta za fizičko vaspitanje.

Popovic, R. (1998). Antropološke determinante u uspehu u ritmicko-sportskoj gimnastici. Niš: SIA.

Popovic, R. Teorijska analiza problematike izbora sportskih talenata i izbora kriterijuma uritmickoj gimnastici. 2002; Godi \{njak 11. 183-207.

Rađo, I., \& Wolf, B. (2002). Kvantitativne metode u sportu; metode za klasifikaciju (diskriminativna i taksonomska analiza). Sarajevo: d.o.o Štamparija Fojnica 